\title{
NETWORKS AND SPEED OF INTERRATIONALIZATION: A MULTIPLE CASE STUDY OF EMERGING MARKET IT FIRMS
}

Renato Dourado Cotta de Mello, Leonardo Gustavo Pereira Barreto, ${ }^{1}$ Clarice Secches Kogut Universidade Federal do Rio de Janeiro - UFRJ/ Coppead, Rio de Janeiro, RJ (Brasil)

ARTICLE DETAILS

\section{Article history:}

Received: 17 December 2019

Accepted: 13 May 2020

Available online August: 01 th 2020

Double Blind Review System

Scientific Editor

Ilan Avrichir

Key words

Internationalization

Network Theory

Information Technology

Emerging Market Multinationals

\begin{abstract}
Objective: This study aims to analyze the internationalization processes of two Brazilian IT firms from the perspective of business networks, seeking to understand the reasons that led these firms to internationalize, the factors influencing the process, and, above all, the importance of business networks.

Method: a qualitative approach, based on multiple case study method was chosen. Main results: It was found that, although the firms internationalized for different reasons and in different ways, the propositions of the Network Theory, to a greater or lesser extent, were sufficiently robust to explain the internationalization processes of the two firms. Furthermore, in the case in which relationship networks played a more relevant role, the speed of internationalization was higher.

Relevance / Originality: The present study addresses two literature gaps noted by Chetty and Stangl (2010): (i) the study of small and medium-sized enterprises in relation to internationalization, innovation, and networks; and (ii) the qualitative testing of the propositions raised by the authors on these subjects.

Contributions: Both managerially - by stressing to managers and entrepreneurs the importance of relationship networks for the internationalization of firms, using real cases - and academically - by contributing to the literature on firm internationalization and network theory (NT).
\end{abstract}

\section{Introduction}

In an increasingly globalized and borderless world, two phenomena have been drawing attention to the process of internationalization of firms: (i) the growing importance of relationship networks in this process, especially for small and medium-sized enterprises (Chetty and Holm, 2000; Coviello and Munro, 1995; Galkina and Chetty, 2015; Lin et al., 2016; Torkkeli et al., 2012) and (ii) the growing participation of emerging-economy based firms in the international market (Cuervo-Cazurra, 2008; Fleury and Fleury, 2007; Lin et al., 2016; Luo and Tung, 2007). While the former has been the focus of numerous and important academic works, the second phenomenon is still less explored (CuervoCazurra, 2008; Fleury and Fleury, 2007). This gap is even more pronounced for studies involving firms from Latin American countries (Cuervo-Cazurra, 2008), such as Brazil.

This study aims to address the two phenomena through the analysis of the internationalization processes of two Brazilian information technology
(IT) service firms. In doing so, it also addresses an important research gap: the internationalization of service firms (Carneiro and Hemais, 2004; Javalgi and Grossman, 2014), responsible for $23 \%$ of total global trade and growing 60\% faster than traditional goods' companies (Mckinsey Global Institute, 2019).

The IT sector is characterized by a high demand for technology and constant innovation. The Brazilian domestic market, which ranks ninth worldwide, stood at USD 47 billion in 2018 compared to the world market worth USD 2.234 billion (Associação Brasileira das Empresas de Software [ABES], 2019). Despite the good domestic performance, exports of Brazilian IT services companies in 2015 amounted to just over USD 1.1 billion (ABES, 2019.) This fact shows there is still room for foreign growth, since this figure is well below that of other developing countries in 2012, such as China (USD 6.2 billion) and India, the largest exporter of IT services with approximately USD 50 billion (Associação Brasileira das Empresas de Tecnologia da Informação e Comunicação, 2013).

Following Santos et al. (2010), who stressed the 
importance of investigating the influence of gradualism, entrepreneur profile, and relationship networks in the process of internationalization of Brazilian firms belonging to the IT sectors, this study sought to identify and understand the main challenges and barriers encountered in the internationalization process of the firms studied, as well as the factors that influenced the move to internationalize, with special emphasis on the role of networks in this process. Thus, the following research question was proposed: What is the role of relationship networks in the internationalization of Emerging Market IT firms?

To answer this question, a literature review on relationship networks was done, starting with the seminal article by Johanson and Mattsson (1988). Two cases of Brazilian IT service providers were described, analyzed, and compared in the light of the theory, thus generating insights and contributions, both managerially - by stressing to managers and entrepreneurs the importance of relationship networks for the internationalization of firms, using real cases - and academically - by contributing to the literature on firm internationalization and network theory (NT). The two cases, coming from developing countries, are studied in depth.

Finally, the present study addresses two additional literature gaps noted by Chetty and Stangl (2010): (i) the study of small and medium-sized enterprises in relation to internationalization, innovation, and networks; and (ii) the qualitative testing of the propositions raised by the authors on these subjects. While the first gap has been subject to a few works since 2010 (about 112 papers published in scientific peer-reviewed journals over the past 10 years, according to a EBSCO search) most are quantitative (over 70\%), based on non-specified or developed contexts (about 90\%) and on large businesses (over 90\%). Moreover, none (according to the same database search ${ }^{2}$ )has answered to Chetty and Stangl's call for a qualitative testing of their 2010's paper propositions. In doing so, we hope to have contributed both to practice - by stressing to managers and entrepreneurs the importance of relationship networks for the internationalization of firms, using real cases - and to literature - with qualitative testing (Doz, 2011; Thomas, 2017) of

\footnotetext{
2 Search on EBSCO database, on April 16 2020. "Innovation" AND "Network" AND "internationalization" on abstracts, AND ("qualitative research" OR qualitative
}

previous propositions (Chetty \& Stangl, 2010) and theory elaboration (Fischer \& Aguinis, 2017) on the relationship between firm internationalization and network theory (NT).

\section{Literature Review}

\subsection{Network theory}

Network theory was considered by Hilal and Hemais (2003) as a natural evolution of the Uppsala model (Johanson and Vahlne, 1977) that emphasized the importance of the relational aspect in the process of firm internationalization.

The Uppsala model describes in a fairly precise way the internationalization of firms located in less internationalized sectors and is especially applicable in cases of large firms pioneering internationalization in their fields of activity (Johanson and Mattsson, 1988). However, the model does not explain the case of rapid internationalization in small firms (Coviello and Munro, 1995), a reason for which it was criticized.

The importance of experiential knowledge in the internationalization process was also questioned. The Uppsala model, in its original version, stresses that such knowledge can only be acquired via the firm obtaining direct experience in foreign markets. However, studies suggest the possibility of transferring experiential knowledge through business networks, which leverage their participants at many levels, such as fundraising (Bell, 1995), a concept later incorporated into the Uppsala model (Johanson and Vahlne, 2009).

The proposal of Johanson and Mattsson in their seminal 1988 article conceives the market as a network of relationships marked by firm interdependence. Coordination takes place through interaction between firms, taking time and effort to develop the relationship with the participants of a network. A network emerges when two or more firms are linked and contextualized as collective actors (Chetty and Holm, 2000). Each firm, seeking to enhance its position in the network, can choose partners with which it wishes to relate. It is worth noting, however, that the choice of partners and the formation of relationships may lead to restrictions for

method OR qualitative study OR interview" on full text"), AND "SMEs OR small and medium enterprises", plus analysis on context and on Chetty \& Stangl (2010) citation. 
the firm with regard to future alliances (Johanson and Mattsson, 1988).

According to NT, a firm's value is directly linked to its interactions with the other parties and to the context in which it interacts; moreover, the firm's development will depend on its positioning in the business network and its ability to use internal and external resources (Hakansson and Snehota, 1989). Additionally, NT assumes that transactions usually occur in established relationships, which require a maturation period. Occasional breaks in relationships usually occur early in the network formation (Johanson and Mattsson, 1988).

Another point worth highlighting is that the relationships of a network can directly influence the firm's decision to internationalize, as well as the choice of a new foreign market to exploit. Moreover, the network often benefits the member firm by enhancing acquisition of knowledge and access to the foreign market's resources (Chetty and Holm, 2000)

Additionally, Johanson and Mattsson (1988) find that firms can develop a relationship in three ways: 1) establishment of new positions for the firm, as in the case of an international extension; 2) increased commitment to a current position, as in the case of increased penetration in a given market; 3 ) increased coordination between different positions, as in the case of international integration.

From these dimensions, the authors created a Market and Firm Internationalization Matrix, which identifies four stages of firm, based on the "degree of internationalization of the firm" and "degree of internationalization of the market," as shown in Figure 1.

\begin{tabular}{c|c|c|c|}
\multicolumn{1}{c|}{} & \multicolumn{3}{c|}{ Degree of internationalization of the market } \\
\cline { 2 - 4 } & & The Early Starter & HIGH \\
\hline $\begin{array}{c}\text { Degree } \\
\text { of the } \\
\begin{array}{l}\text { Internation- } \\
\text { alization } \\
\text { of the firm }\end{array}\end{array}$ & LOW & $\begin{array}{c}\text { The Late } \\
\text { Starter }\end{array}$ \\
\cline { 2 - 4 } & HIGH & $\begin{array}{c}\text { The Lonely } \\
\text { International }\end{array}$ & $\begin{array}{c}\text { The } \\
\text { International } \\
\text { Among } \\
\text { Others }\end{array}$ \\
\hline
\end{tabular}

Figure 1. Internationalization Matrix

Source: Johanson and Mattsson (1988: 310)

The Early Starters are characterized by a low degree of internationalization of the market and of the firm. In this case, the sector in which they are inserted has a low degree of internationalization and does not exert significant pressure in terms of internationalization of the firm. Internationalization occurs gradually and to markets nearby, in an attempt to lessen the need for adaptations (Johanson and Mattsson, 1988).

The next stage is the Lonely International, i.e., the firm becomes more internationalized despite the low degree of internationalization of the market. This gives the firm an advantage over the competition because it develops its positioning in the business network abroad before others do, and thus has a higher chance of optimizing resources through the coordination and integration of international activities (Johanson and Mattsson, 1988).

In the case of Late Starters, the market is already very internationalized when the firm takes its first steps in this direction. In this case, the firm suffers from having little knowledge of the market and has difficulties establishing a position in the network, which already has well-defined relationships. For this reason, the firms must adapt to the consumer or influence their preferences (Johanson and Mattsson, 1988).

International among Others is characterized by the high degree of internationalization of the firm and the market. In this case the firm, already embedded in the business network, has greater access to external resources.

The firm can also leverage its experience to enter new markets without wasting resources (Johanson and Mattsson, 1988). NT also helps explain the internationalization phenomenon of small and medium-sized firms, which use resources and knowledge of their business networks to enter new markets. Company strategy is then not only comprised of its own individual movements, but also 
of coordination of the entire network (Coviello and Munro, 1995).

Coviello and Munro (1995) also note that the competitiveness of the sector can be an important factor driving the process of firm internationalization. According to the authors, high-tech and innovative sectors tend to be more internationalized due to high competitiveness. Forsgren and Hagstrom (2001) studied the internationalization dynamics of firms in the technology sector and also found that - unlike the incremental process marked by the chain of establishment suggested by the original Uppsala model - the internationalization of these firms occurred in an accelerated way and was influenced by their business networks.

Therefore, authors such as Lin et al. (2016) attribute to relationship networks one of the main factors for the rapid internationalization of the socalled born-globals (Rennie, 1993), i.e., firms that internationalized within three years of inception, that derive at least $25 \%$ of sales from the foreign market, and that, rather than following a gradual process of internationalization, do so shortly after inception (Lin et al., 2016).

The study by Torkkeli et al. (2012) corroborates this view, finding that belonging to a good relationship network is positively correlated to the propensity of small and medium-sized firms to internationalize, as well as their international performance.

\subsection{Revised Uppsala model}

Johanson and Vahlne, the authors of the Uppsala model, in order to account for the increasing speed of the internationalization process included NT in their revised model. According to this pattern, the internationalization of firms is not necessarily gradual and does not necessarily adhere to the stages establishment chain and psychic distance (Johanson and Vahlne, 2003).

The Uppsala model came to consider the internationalization process from a perspective of relations between firms that are part of an integrated business network. In this sense, the success of internationalization also depends on firms' ability to establish connections and ensure a good position in this network (Johanson Mattsson, 1988).

For this reason, Carvalho and Dib (2013) contend that the revised Uppsala model positions relationships as the focal point of the internationalization process. Experiential knowledge - so important in the original Uppsala Model - can now be obtained via the relationships between the actors in the business network. With such a network, a firm does not need to operate directly in a country to gain knowledge, because that knowledge can instead be passed on by its business network partner (Johanson and Vahlne, 2009).

Likewise, the firm's commitment is basically defined by exchange activities, and the market is conceived as a dynamic network of relationships. In this sense, the partners' commitment to the business network is a key factor for the success of an organization's internationalization (Johanson and Vahlne, 2009).

Knowledge and commitment continue as central elements of the Uppsala model; however, these variables are seen in a new light that values the firm's ability to obtain partners, as well as systematizing a learning process through relationship networks (Johanson and Vahlne, 2009).

Finally, the revised Uppsala model removes the establishment chain as central to the internationalization process and admits that firms can often skip steps, even including different entry modes, such as joint ventures. The revised model also diminishes the importance of psychic distance in the internationalization process, since it assumes that a firm can minimize this sense of foreignness within the network.

In this case, the cultural and institutional differences become less relevant, because what makes the passing on of knowledge viable is being part of the business network. For this reason, there is a downside to being outside the network that firms should consider (Carvalho and Dib, 2013).

In 2013, Vahlne and Johanson update the model once again, further consolidating the importance of networks in the process of firm internationalization. They conclude that the firm's position in the network is the result of relationships, commitments, and past knowledge, as well as the starting point for new actions (Vahlne and Johanson, 2013).

\subsection{Combining network theory, innovation and internationalization}

Discerning a gap in the work combining the literatures of networking, innovation and 
internationalization, Chetty and Stangl (2010) carried out a study of 10 New Zealand software firms, classifying them according to the matrix represented by Fig. 2 below.

\begin{tabular}{|c|c|c|}
\hline & \multicolumn{2}{|c|}{ Innovation } \\
\hline Internationalization & Incremental & Radical \\
\hline Incremental & Group 3 & Group 4 \\
\hline Radical & Group 1 & Group 2 \\
\hline
\end{tabular}

Figure 2. Innovation and internationalization matrix Source: Chetty and Stangl (2010: 1733)

Thus, the authors consider internationalization to be radical when a firm (a) begins its internationalization process within three years of inception and (b) its foreign sales exceed $75 \%$ of total sales and come from at least 20 countries. Incremental internationalization, on the other hand, is when the firm (a) has been in business for at least three years and (b) foreign sales account for no more than $60 \%$ of revenues come from fewer than 5 countries. Moreover, radical innovation refers to products or processes that represent a clear rupture with existing practices, with consequent changes in the firm's capabilities. Incremental innovation, therefore, is when new products or services represent only a marginal departure from existing practices.

As a result, Chetty and Stangl (2010) arrived at the following propositions:

$P 1$. Firms with a radical innovation and diverse network relationships are more likely to have a radical internationalization process;

P2. Firms with an incremental innovation and relationship networks with financial agents are likely to have a radical process of internationalization;

P3. Firms with a radical innovation in a rapidly changing technological environment that lack relationships with financial agents are more likely to have an incremental internationalization process; and

P4. Firms with incremental innovation that are small, young and with few relationships are likely to internationalize incrementally.

Finally, the authors suggest that future research should include qualitative and quantitative tests of these propositions in other countries and contexts.

\section{Research Method}

The research approach used in this work is qualitative, in order to gain an in-depth understanding of the internationalization process of the two software firms studied. The methodology chosen was the multiple case study, which allowed a comprehensive investigation to be made of the main aspects involved in the internationalization processes of the firms analyzed and the role of the relationship networks in these processes.

The choice of qualitative research is justified in subject areas that call for a deep understanding or that do not have well delineated boundaries (Creswell, 2004), as is the case with this study, since the investigation of the process of firm internationalization considers subjective aspects of managers' decision-making processes.

Thomas and Myers (2015) point out that the case study is particularly efficient in describing a phenomenon from multiple perspectives, thus enabling a richness of analysis and providing insights into the focus of study. In this sense, although the case study method does not seek generalizations, it has been used in studies that have obtained insights in several areas (Thomas and Myers, 2015).

The choice of this method is also consistent with the recommendations of Ghauri (2004), who emphasizes that case studies are appropriate in the area of international business because with open questions the interviewer is able to explore and discern multiple points of view (Ghauri, 2004). Finally, it is worth noting that Hoang and Antoncic (2003) call for more qualitative and inductive research in the study of relationship networks in international entrepreneurship in order to introduce new theoretical ideas and stimulate future work.

A few scholars, such as Doz (2011) and Thomas (2017), go even further, arguing that "the 
multidisciplinary nature of IB makes qualitative research particularly valuable in that it allows us to build and test new theories, illustrate and exemplify new phenomena and surface contextual differences between countries" (Birkinshaw, Brenen \& Tung, 2011, p.5), which were our objectives with this paper.

\subsection{Selection of cases}

The firms studied were identified by researching various information media, such as magazines and newspapers, and websites specialized in entrepreneurship and information technology. For a firm to qualify, it had to be (i) of Brazilian origin; (ii) in the IT services sector; (iii) and have international activities in at least one foreign country.

In addition to these criteria, it was essential that the firms be able to provide the necessary interviews through their managers. Thus, according to the established criteria and managers' confirmation of their availability for interviews, the firms chosen were Muxi and Wett (Wett being a fictitious name, at the firm's request to remain anonymous).

\subsection{Data collection and analysis methods}

The case study is a research method that allows the in-depth study of a phenomenon. Therefore, using several data sources to understand complex phenomena from different perspectives is key (Yin, 2009). In addition, a variety of data sources is needed to enable triangulation for a better research base (Eisenhardt, 1989).

According to Thomas and Myers (2015), the case study involves an analysis from various angles to understand how the elements of the case connect, given that multiple perspectives help explain a phenomenon and how it manifests. In order to follow this recommendation, this research collected both primary and secondary data. Secondary data on the sector were obtained from the websites of Brazilian government institutions, such as IBGE, Softex (Association for the Promotion of Brazilian Software Exports), and IT trade magazines. Regarding the firms, 15 different sources were consulted and provided the basis for the interviews. Sources included news stories, information on the companies' own websites, promotional materials, and a previous case study of one of the companies. There was also a previous interview with the founder of Muxi, conducted at CENI/UFRJ (Prates, 2010).
The primary data collection was done through two in-depth interviews, covering three major sources: one joint interview with the CEO and marketing director of Wett, and another with the CEO of Muxi. The interviews lasted about two hours each; they were recorded and transcribed in a way that made it possible to construct the cases. Following the interviews, telephone calls were made to the interviewees to clarify any questions and obtain additional information needed to complement the cases.

\section{The Cases}

\subsection{The Muxi case}

Muxi was founded in 1993 in Rio de Janeiro. The firm develops solutions for payment transactions, especially in the areas of capture, routing/authorization and settlement, serving a variety of business segments. The firm's technology is multichannel and accessible via several devices, including point of sale (POS), mobile phone, tablet, PC, and website. The customer portfolio is diversified and includes important companies, such as Banco do Brasil and Cielo (formerly VisaNet). Cielo, a successful partnership according to the firm, is the biggest player in the world in terms of POS, with more than 1.8 million in Brazil (CIELO, 2016).

Including Brazil, the firm has operations in five countries, operating in over three million POS in Brazil and other foreign markets; it has more than 100 employees spread over three offices in Rio de Janeiro, São Paulo and Mexico City. The firm is planning on opening two additional foreign offices in the near future, one in the USA and one in Peru.

Muxi's big jump came in 2001 with the creation of a product that had a great impact on Brazil's payment industry: a web-based browser that runs on the operating system of POS terminals, a move that enabled the firm to take control of several resources.

\subsubsection{Internationalization}

The internationalization of Muxi began as a personal project of its founder, who did not want to run the risk of losing opportunities in the foreign market.

"We know we're going to grow a lot here, and we know we can do the same outside of Brazil. Sometimes I'm struck by this desperation not to 
lose the opportunities the foreign market offers." (Alexandre Pi, Muxi founder).

The global nature of the payment market was another important driver for Muxi's internationalization process. According to Luis Felipe Cavalcanti (Muxi CEO), the global payment standards established by the credit card brands favor the firm's internationalization by standardizing procedures.

Its first international expansion attempt was shortly after their main product rollout, in 2001, by participating in major European and US trade-shows (Prates, 2010). However, the lack of planning and lack of knowledge of the payment market contributed to the failure of these early forays.

"My strategy was to go to every event [...]. We never did close a deal; but everyone got to know us [...]. This was very difficult: we created a product that nobody wanted to buy. [...] It was a terrible experience." (Alexandre Pi, Muxi founder)

The firm's real first international market was Mexico in 2005. The firm was able to sell software licenses in an internationalization process that originated from Brazil, but without the presence of local commercial representatives.

In 2007, the internationalization project was put on hold to focus on to the project with Cielo, but was resumed in 2009 by the founder himself:

"[...] my goal was close the new contracts with Cielo, and then I'd leave Brazil to advance our internationalization process. It's a personal project. I have no more challenges in Brazil. The hard part is already done." (Alexandre Pi, Muxi founder).

In that same year (2009), the firm was selected to participate in G-Lab, a consulting service provided by MIT students, with the objective of outlining a strategy to enter the US market; the strategy was three-pronged (Prates, 2010): before opening an office of its own, which could be costly and ineffective, the firm should (i) acquire market knowledge; (ii) await opportunities to invest in this market; (iii) and, before entering the US, know and be known by the American market by establishing a business network. From 2009 to 2015 the firm worked on building a relationships network with the help of representatives.

In parallel, from 2010-2011 and while also studying at MIT, Luis Felipe Cavalcanti drew up a new strategic plan for the firm to leverage its operations inside and outside Brazil in the prepaid market. The firm should guide its global strategy based on criteria such as distance from Brazil (cultural and administrative/geographic/economic factors) and market attractiveness. Thus Mexico, Chile, Colombia and Peru were chosen. Luis Felipe Cavalcanti also noted that Brazil's technological leadership in the South American payment market was important in choosing these countries.

In 2012, Luis Felipe Cavalcanti became the CEO of Muxi, and an international board was created to coordinate the firm's efforts in foreign markets. The firm began its activities in Colombia in 2012 and in Peru in 2013, both through local representatives. Entry using local representatives has been a firm practice, enabled by its representatives' commercial contacts and knowledge of the culture and the local market. The firm expects its forays into Peru and Colombia to help leverage operations in the region:

\section{"Both Visanet-Peru and Redeban (Colombia) are the largest purchasers, and both are in the implementation phase. We believe (and are working so they become regional cases) that from there we can close other projects in Latin America and Mexico. The United States is the next target." (Luis Felipe Cavalcanti, Muxi CEO).}

Currently, Muxi has an office in Mexico, representatives in Colombia, Argentina, and Peru, and is assessing business prospects in Chile. The relative weight of foreign sales (previously 1\%) grew to $6 \%$ in 2015.

\subsection{The Wett case}

Wett was founded in 2008 by André Lima (CEO), Danilo Silva (CTO), and Hilton Alves, all with excellent academic backgrounds and relevant professional experience in the industry as a global provider of Big Data Analytics for the internet of things (IOT). Initially, they marketed their software through licensing agreements with clients operating in three segments: telecommunications, energy, and transport/logistics.

The firm is based in Rio de Janeiro, has an office in São Paulo, and is setting up another in London, where it already has a sales team to service the European market. The technical structure is located in Brazil, as is customer service to national and international clients. A small technical structure is maintained in Canada for legal reasons. By 2016, the firm had customers in Chile, Colombia, Peru, Argentina, Mexico, Bolivia, Canada, United States and Italy. The 
firm has approximately 100 employees, mostly in Brazil. Between $40 \%$ and $60 \%$ of sales are foreign.

Wett's international contracts are concentrated in the telecom sector. André, who worked for more than 10 years in a major telephone company, highlights the firm's knowledge in this area as a key aspect to Wett's success in the telecom segment. Moreover, its network of relationships in this sector, built over the years, was also an important aspect.

In addition to the founding partners, over the years the firm has received capital contributions from significant investors. The firm's first investor was Intel Capital in 2013, followed by Citrix, which invested that same year. Also in 2013, the firm acquired Telematics, a company active in the field of transport and logistics. In 2015, the firm sought additional partners for a new round of investment. This time, Qualcomm, DGF, and Intel (in a second round) made total investments of some BRL 40 million.

\subsubsection{The internationalization of Wett}

The firm's telecommunications segment has 100\% of its contracts in foreign currency and these account for the bulk of revenues. The scenario is different in the transportation and logistics segment, where the firm has grown in recent years and in which it operates only in Brazil.

André highlights two key factors for Wett's internationalization: the high degree of internationalization in the telecommunications sector and the relationship with Nokia. In his opinion, a telecom network in Brazil is not much different from anywhere else. Thus, when a company is qualified to compete in Brazil, it is qualified to compete worldwide:

[...] "When you have a telecom network - for example, here in Brazil - it's not much different from networks elsewhere in the world. Suppliers are usually the same too: Those that service Brazil are the same ones that service United States and Europe; so it's a sector that's already globalized. So, as you prepare to compete in Brazil, you are practically already qualified to compete in any other country. [...] For example, in 2012, we bid for a contract in Indonesia: not so much as a comma was changed for the sales pitch [...]." (André, CEO Wett).

However, this is not true for all the segments in which Wett operates. According to André, the differences between the problems encountered in
Brazil and in other countries in the logistics segment make internationalization in this segment more complex.

The relationship with Nokia began in 2009, when the firm won a bid to provide services to this company. Nokia sought to complement its portfolio of offerings with the services that Wett had developed in order to offer solutions beyond hardware. As a result, Nokia invited firms to submit proposals for provision of this type of service. Wett was awarded the contract and since then has become Nokia's standard tool in several countries.

Thus, Wett did not prospect overseas customers, since Nokia had introduced the firm in the international market. The demand came to them.

However, there were some occasions whereby demands originated through referrals from people who already knew Wett. This was the case in Canada, where Brazilians recommended the firm to a mobile operator in that country.

"But we also had other customers that found us
other than through Nokia. [...] It turns out that
in the telecommunications market, because it is
so concentrated and people switch jobs often, a
person who has already worked with an
operator, who has already used our tool, will go
and work in another operator. That's what
happened in Canada" (André, Wett CEO).

Despite recent investments from major companies such as Intel and Qualcomm, the company remains under the control of the founders, who together are a majority on the board and have full control of management. However, in addition to the benefits of invested capital, investors offer important support, especially in the commercial area, mediating contacts with potential clients and ensuring space for stands at trade shows and conventions.

"... they (the investors) provided support by investing their own capital in the commercial and technological area, the latter being more focused on sharing experiences. We received a lot of support in relation to getting introductions to customers. They hold frequent events in which they fit us into workshops so we can present our portfolio. So you're obviously getting backed by Intel, which is a great advantage" (André, CEO da Wett).

He continues:

"In conferences too. There is a very large conference that's held once a year in Barcelona. 
Networks and Speed of Internationalization: A Multiple Case Study of Emerging Market IT Firms

This year we did have a stand of our own; but Qualcomm set aside a space inside their stand, which is huge, to present our products. Intel had reserved meeting rooms whereby they arranged meetings for us with several potential customers".

\section{Analysis}

Table 1. Below summarizes the main characteristics of the firms studied

TABLE 1: Summary of companies

\begin{tabular}{|c|c|c|}
\hline Company & Muxi & Wett \\
\hline Year of inception & 1993 & 2008 \\
\hline Internationalization & 2005 & 2009 \\
\hline Reason for first export & Will of the founder & Fortuitous (networks) \\
\hline Company size & + 100 employees & Approx. 100 employees \\
\hline $\begin{array}{l}\text { Percentage of revenues from } \\
\text { foreign sales }\end{array}$ & $6 \%$ & $40 \%$ to $60 \%$ \\
\hline Business model & $\mathrm{B} 2 \mathrm{~B}$ & $\mathrm{~B} 2 \mathrm{~B}$ \\
\hline Products exported & Payment solutions & Data analytics solutions \\
\hline Foreign markets served in 2016 & $\begin{array}{l}\text { Mexico, Peru, Colombia, } \\
\text { United States }\end{array}$ & $\begin{array}{l}\text { Chile, Colombia, Peru, } \\
\text { Argentina, Mexico, Bolivia, } \\
\text { Canada, United States, Italy }\end{array}$ \\
\hline
\end{tabular}

Source: prepared by the authors

\subsection{The network model and the cases studied}

As mentioned previously, NT assumes that the firm can be positively influenced performance-wise when it is part of a network (Chetty and Holm, 2000; Hakansson and Snehota, 1989; Torkkeli et al., 2012). Being in a relationships network can mean access to more resources and more knowledge. A firm within the network can utilize the knowledge of its business partners to enter new markets, thereby reducing the need to obtain experiential knowledge exclusively through in-house operations (Johanson and Mattsson, 1988).

When comparing the two cases presented here, both firms, to a greater or lesser extent, have taken advantage of and benefited from their relationship networks in their internationalization processes.

Muxi systematically used commercial representatives to obtain knowledge about the foreign markets. The company used its representatives not only to obtain greater knowledge about the culture and mode of doing business in these places, but also to increase its market penetration via its representatives' relationship networks, an observation consistent with Coviello and Munro (1995) and Chetty and Holm (2000).
Muxi also took the time and effort to expand its network of relationships based on its view that they are key to internationalization. Therefore, it acts jointly with representatives to ensure customer needs are met. In Peru, the firm is preparing to set up an office to provide its customer Visanet-Peru additional support and strengthen its relationship in the belief that good performance may lead to new projects in other countries in the region.

But the relationship network was even more important in Wett's internationalization, because the first and most significant foreign orders came through Nokia. Thus, the firm did not prospect customers or choose the markets in which to operate. According to the CEO:

We did not choose; we were chosen. We were
not active; we did not seek internationalization;
it happened. The demands from these countries
came, and we simply serviced them. We did not
prospect in these countries in order to enter
them (André, Wett CEO).

Even in other cases, such as in Canada, the firm was recommended by people who were already familiar with Wett - another benefit derived from networks.

The company's relationship with investors is another highlight, because it expanded the 
availability of financial and non-financial resources for the firm. In addition to providing funding, these investors were part of other large relationship networks and helped Wett by holding meetings between the company and potential customers, arranging for space in stands at international fairs and conferences, and sharing technological support and experiences.

Thus, consistent with the findings of Lin et al. (2016), the relationship networks played an important role in the rapid internationalization of Wett, just one year after its founding, as well as in its good performance, with foreign business ranging from $40 \%$ to $60 \%$ of annual revenues - also in line with the findings of Torkkeli et al. (2012).

Another similarity between the two firms, and in agreement with Coviello and Munro (1995), would be the internationalization of the sectors in which both operate. However, the similarities of the two internationalization processes are limited to these variables.

Using the internationalization matrix of Johanson and Mattsson (1988: 310), Wett and Muxi are located in different quadrants. Although both of them operate in internationalized sectors, Muxi presented characteristics of a "late entrant" during its internationalization process: difficulties in establishing a position in the network and the need for the firm to adapt to the demand (see remark by company CEO, page 10 of this study), thus requiring local representatives to assist in the process. Consequently, the firm took longer to establish itself and to expand internationally comparing to the case of Wett.

Regarding Wett, besides acting in an internationalized sector, the firm can be considered an "international among others," i.e., a firm already inserted in the business network, with greater access to external resources, and benefiting from its experience to enter new markets without wasting resources.

\subsection{The Chetty and Stangl model (2010) and the cases studied}

While neither of the two firms has undergone a typical radical internationalization (75\% of total sales from foreign markets and serving more than 20 countries), Wett is closer to that than Muxi, since it internationalized just a year after inception, is present in more countries (ten versus only five) and has a much more significant proportion of its sales from the foreign market (40-60 percent, versus 6 percent). However, neither can Wett's internationalization process be considered incremental, as defined by Chetty and Stangl; thus, it occupies an intermediate position between groups 2 and 4 in Figure 3 below.

With regard to innovation, Wett did present a radical innovation process, with a clear rupture with existing practices and consequent changes in the firm's capabilities (Chetty and Stangl, 2010). In contrast, Muxi advanced internationally with only incremental innovations.

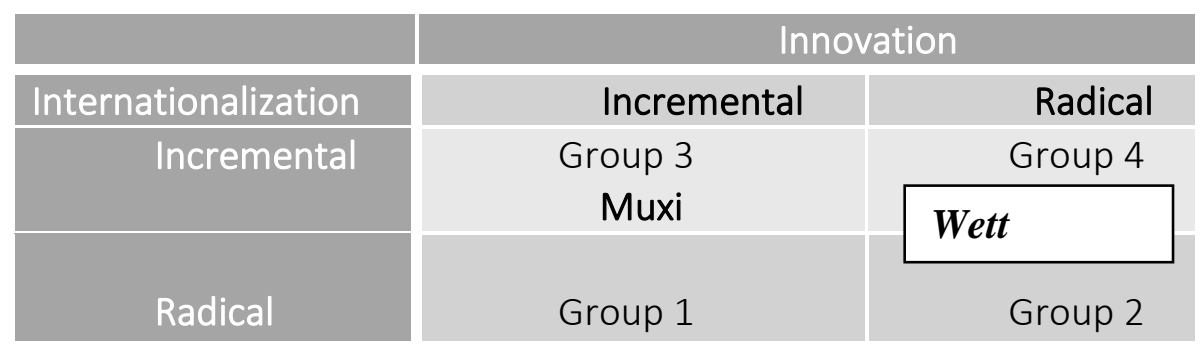

Figure 3. Innovation and internationalization matrix

Source: adapted from Chetty and Stangl (2010)

There was not sufficient empirical evidence to fully confirm the proposals of Chetty and Stangl (2010), as explained below:

P1. Firms with radical innovations and broad relationship networks tend to present a radical internationalization process.
In Wett's case, the internationalization process was, if not radical, at least accelerated.

Chetty and Stangl (2010), according to the proposed typology, classify relationship networks as broad or restricted. Although Wett's relationships network is apparently broader than Muxi's, network size does not seem to be the main driver of success in 
its internationalization process. Rather, the strength, importance, and even bilateral dependence of these relationships should be considered.

P2. Firms with incremental innovation and relationship networks with financial agents tend to present a radical internationalization process.

No empirical evidence supporting this proposition was observed in Wett or Muxi.

P3. Firms with radical innovation in an environment of rapid technological change, but, if they lack relationships with financial agents, tend to present an incremental internationalization process.

No empirical evidence supporting this proposition was observed in Wett or Muxi.

P4. Firms with incremental innovation that are small, young, and with few relationships tend to internationalize incrementally.

Muxi's case presents empirical evidence that supports this proposition, since over the course of its development, innovations adopted by the firm were incremental, as was its internationalization process, developed through a relatively restricted network of relationships.

\section{Conclusions}

Muxi and Wett are two firms that internationalized for different reasons and in different ways. However, the propositions of NT, to a greater or lesser extent, were robust to explain the internationalization processes of both, as expected with IT firms.

Consistent with the findings of Coviello and Munro (1995) and Chetty and Holm (2000), Muxi used its market knowledge and the contacts of its representatives to establish itself overseas. This facilitated the firm's entry in different markets, both in relation to mode of doing business and in relation to the network of contacts of these representatives.

With Wett, their client portfolio and therefore the choice of countries to enter was the result of recommendations from their networks of contacts. This pattern is consistent with the concepts described by Chetty and Holm, (2000) and Coviello and Munro (1995). Thus, (i) Wett's exports originated through Nokia; (ii) additional contracts were then obtained via recommendations by people who already knew or had worked with the firm; and (iii) Wett's investors, as international organizations, besides increasing the availability of resources to the company, also assisted with technological, strategic, and commercial support.

However, it is worth noting that in the case of Wett, the relationship networks played an important diffuser/accelerator role that was highly relevant in the firm's internationalization. Although both firms operate predominantly in sectors that follow global standards, which facilitate internationalization, this process occurred just one year after Wett's inception. In contrast, twelve years passed in Muxi's case, even though internationalization had been a stated objective of the founder from the firm's earliest days. In addition, ten years after the start internationalization, revenues from Muxi's international operations accounted for just six percent of total revenues, while at Wett this number was around 40-60 percent within seven years of the start of internationalization. These differences both in terms of time elapsed to start international activities and the importance of these activities for total firm revenues - can be explained by the importance of the relationship networks in the process: stronger and more decisive in the case of Wett (which had an almost reactive internationalization in response to the demands of its network); weaker and less impactful in the case of Muxi (which always had a more proactive role, seeking its own international opportunities).

Similarly, even though significant innovation is by itself a driver of growth, as Chetty and Stangl (2010) pointed out and could be observed in Wett's case, the effects of a significant innovation are boosted when the firm is part of a relationship network, catalyzing the internationalization process, accelerating it or, in some cases, making it radical.

\section{Contributions, limitations and recommendations for future studies}

The present article aims to contribute (i) businesswise, to emphasize to managers and entrepreneurs, using real cases, the importance of relationship networks for the internationalization of firms; and (ii) academically, by contributing to the literature of firm internationalization and NT with an in-depth case study that addresses the two major research gaps (regarding firms from emerging countries and regarding service providers), as well as Chetty and Stangl's (2010) call for papers that qualitatively test 
their theoretical propositions in different contexts, thus contributing with theory elaboration (Fischer \& Aguinis, 2017).

In addition to the limitations of the method, limitations arise from the fact that both cases are IT service providers and Brazilian firms.

For future studies, similar qualitative research can be done in other sectors, both in Brazil and in other

\section{References}

Associação Brasileira das Empresas de Software (2019) Brazilian software market scenario and trends. Available at: http://central.abessoftware.com.br/Content/Upload edFiles/Arquivos/Dados\%202011/ABESEstudoMercadoBrasileirodeSoftware2019.pdf

Associação Brasileira das Empresas de Tecnologia da Informação e Comunicação (2013) Central de informações: mercado de TIC. São Paulo: BRASSCOM. Available at:

http://www.brasscom.org.br/brasscom/Portugues/d etInstitucional.php?codArea=3\&codCategoria $=21$

Bell J (1995) The internationalization of small computer software firms. A further challenge to "stage" theories. European Journal of Marketing, 29(8): 60-75.

Birkinshaw, J., Brannen, M. and Tung, R. (2011). From a distance and generalizable to up close and grounded: Reclaiming a place for qualitative methods in international business research. Journal of International Business Studies 42, 573-581 (2011). https://doi.org/10.1057/jibs.2011.19

Carneiro J and Hemais C (2004) Modelo de Uppsala permite entender o processo de internacionalização de empresas de serviços? In: Hemais C. (Org.) O desafio dos mercados externos: Teoria e prática na internacionalização da firma. Rio de Janeiro: Mauad.

Carvalho C and Dib L (2013) Reconciliando o modelo de uppsala com a perspectiva de networks: Revisão crítica e integrativa. Revista de Administração FACES Journal, 12(2): 13-36, 2013. developing countries, in the same sector and/or other. In addition, broader quantitative studies are recommended for proper testing and statistical generalization of findings. Finally, investigating if IT firms have any specific characteristics that interfere in their internationalization process, positively or negatively, regarding relationship networks.

Chetty S and Holm DB (2000) Internationalization of small to medium-sized manufacturing firms: a network approach. International Business Review, 9(1): 77-93.

Chetty, SK and Stangl LM (2010) Internationalization and innovation in a network relationship context. European Journal of Marketing, 44(11/12): 1725-1743.

CIELO. (2016) Saiba tudo sobre a Cielo. Available at:

https://www.cielo.com.br/wps/portal/Home/interna s/conheca

Coviello NE and Munro H (1995) Growing the entrepreneurial firm: networking for international market development. European Journal of Marketing, 29(7): 49-61.

Creswell J. (2004) Research Design: qualitative, quantitative, and mixed method approaches. 2 ed. Thousand Oaks, CA: Sage.

Cuervo-Cazurra A (2008) The multinationalization of developing country MNEs: the case of multilatinas. Journal of International Management, 14(2): 138154.

Doz, Y. (2011). Qualitative research for international business. Journal of International Business Studies, 42(5), 582-590. Retrieved April 16, 2020, from www.jstor.org/stable/29789446

Eisenhardt, KM (1989) Building theories from case study research. The Academy of Management Review, 14(2004): 532-550.

Fisher, G., \& Aguinis, H. 2017. Using theory elaboration to make theoretical advancements. Organizational Research Methods. doi: 10.1177/1094428116689707. 
Fleury A and Fleury M (2004) Internacionalização das empresas brasileiras: em busca de uma abordagem teórica para os late movers. In: Internacionalização e os países emergentes. São Paulo: Atlas, 2007.

Forsgren, M and Hagström P (2001) Ignorant internationalization? The Uppsala model and internationalization patterns for internet-related firms. Communication \& Strategies, 3(4): 291-305.

Galkina T and Chetty S (2015) Effectuation and networking of internationalizing SMEs. Management International Review, 55(5): 647-676.

Ghauri P (2004) Designing and conducting case studies in international business research. In: Marschan-Piekkari R and Welch C (Ed) Handbook of qualitative research methods for international business. Cheltenham, U.K.: Edward Elgar.

Hakansson H and Snehota I (1989) No business is an island: The network concept of business strategy. Scandinavian Journal of Management, 5(3):187-200.

Hilal A and Hemais CA (2003) O processo de internacionalização na ótica da Escola Nórdica: evidências empíricas em empresas brasileiras. Revista de Administração Contemporânea, 7(1): 109124.

Hoang H and Antoncic B (2003) Network-based research in entrepreneurship: a critical review. Journal of Business Venturing, 18(2):165-187.

Javalgi R and Grossman D (2014) Firm resources and host-country factors impacting internationalization of knowledge-intensive service firms. Thunderbird International Business Review, 56(3): 285-300.

Johanson J and Mattsson L (1988) Internationalization in Industrial Systems: A Network Approach. In: Orsgren M, Holm U and Johanson J (Ed) Knowledge, Networks and Power. London: Palgrave Macmillan.

Johanson J and Vahlne JE (1977) The internationalization process of the firm: a model of knowledge development and increasing foreign market commitments. Journal of International Business Studies, 8(1): 23-32.
Johanson J and Vahlne JE (2003) Business relationship learning and commitment in the international process. Journal of International Entrepreneurship, 1(1):83-101.

Johanson J and Vahlne JE (2009) The Uppsala internationalization process model revisited: from liability of foreignness to liability of outsidership. Journal of International Business Studies, 40(9):14111431.

Lin S, Mercier-Suissa C and Salloum C (2016) The Chinese Born Globals of the Zhejiang Province: a study on the key factors for their rapid internationalization. Journal of International Intrepreneurship, 14(1):75-95.

Luo $Y$ and Tung RL (2007) International expansion of emerging market enterprises: A springboard perspective. Journal of International Business Studies, 38(4):481-498.

Mckinsey Global Institute (2019). GLOBALIZATION IN TRANSITION: THE FUTURE OF TRADE AND VALUE CHAINS. Retrieved from https://www.mckinsey.com/featuredinsights/innovation-and-growth/globalization-intransition-the-future-of-trade-and-value-chains. Accessed on 16th April, 2020

Prates RP (2010) O paradigma eclético de Dunning e a internacionalização de uma empresa brasileira de software. Monograph. Universidade Federal do Rio de Janeiro, Brazil.

Rennie MW (1993) Born global. McKinsey Quarterly, 4:45-52.

Santos RCM, Chauvel MA and Bertrand H (2010) Internacionalização de pequenas empresas brasileiras de tecnologia. Gestão \& Regionalidade, 26(76):43-62.

Thomas G and Myers K (2015) The anatomy of the case study. London: Sage.

Thomas, J. (2017). Scholarly Views on Theory: Its Nature, Practical Application, and Relation to World View in Business Research. International Journal of Business Management, Vol. 12(9), 2017 DOI:10.5539/ijbm.v12n9p231. Available at SSRN: https://ssrn.com/abstract=3023509 
Torkkeli L, Puumalainen K, Saarenketo S and Kuivalainen O (2012) The effect of network competence and environmental hostility on the internationalization of SMEs. Journal of International Entrepreneurship, 10(1):25-49.

Vahlne JE and Johanson J (2013) The Uppsala model on evolution of the multinational business enterprise: from internalization to coordination of networks. International Marketing Review, 30(3):189-210.

Yin RK (2009) Case study research: design and methods. Thousand Oaks: Sage.

\section{About Authors}

Renato Dourado Cotta de Mello - Universidade Federal do Rio de Janeiro - UFRJ/ Coppead, Rio de Janeiro, RJ (Brasil).Email: renato@coppead.ufrj.br Orcid id: https://orcid.org/0000-0003-2345-1202

Leonardo Gustavo Pereira Barreto - Universidade Federal do Rio de Janeiro - UFRJ/ Coppead, Rio de Janeiro, RJ (Brasil). Email: leonardogpereirabarreto@gmail.com

Clarice Secches Kogut - Universidade Federal do Rio de Janeiro - UFRJ/ Coppead, Rio de Janeiro, RJ (Brasil). Email: clarice.kogut@coppead.ufrj.br Orcid id: https://orcid.org/0000-0002-4760-654X 


\title{
REDES E VELOCIDADE DE INTERNACIONALIZAÇÃO: UM ESTUDO DE CASO MÚLTIPLO DE EMPRESAS DE TI DE MERCADOS EMERGENTES
}

\author{
Renato Dourado Cotta de Mello, Leonardo Gustavo Pereira Barreto, Clarice Secches Kogut \\ Universidade Federal do Rio de Janeiro - UFRJ/ Coppead, Rio de Janeiro, RJ (Brasil)
}

\section{DETALHES DO ARTIGO}

\section{Histórico do Artigo:}

Recebido: 17 de Dezembro de 2019

Aceito: 13 de Maio de 2020

Disponível online: 01 de Agosto de 2020

Sistema de revisão "Double blind review"

Editor Científico

Ilan Avrichir

\section{Palavras-chave:}

Internacionalização

Teoria da Rede

Tecnologia da Informação

Multinacionais de Mercados Emergentes

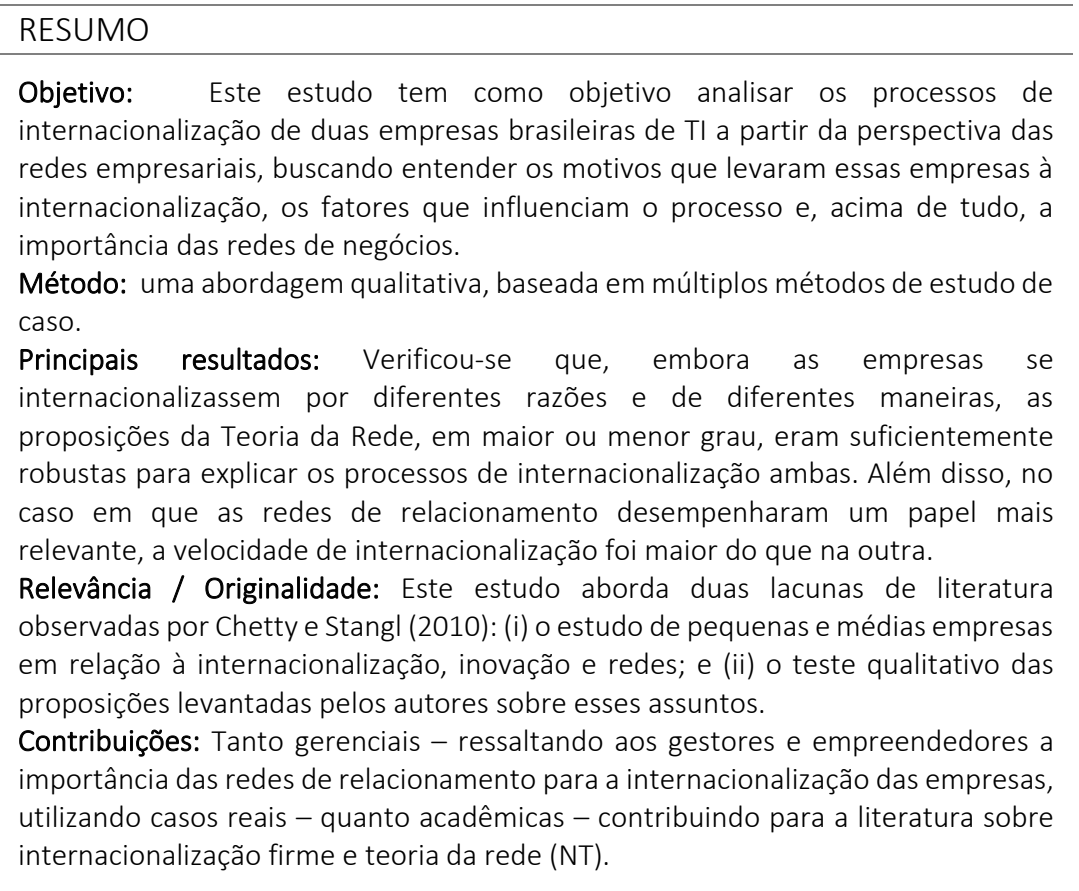




\section{REDES Y RAPIDEZ DE INTERNACIONALIZACIÓN: UN ESTUDIO DE CASO MÚLTIPLE DE EMPRESAS DE TI DE MERCADOS EMERGENTES}

Renato Dourado Cotta de Mello, Leonardo Gustavo Pereira Barreto, Clarice Secches Kogut Universidade Federal do Rio de Janeiro - UFRJ/ Coppead, Rio de Janeiro, RJ (Brasil)

\section{HISTORIA DEL ARTÍCULO}

Historia del Artículo:

Recibido: 17 de Diciembre de 2019

Aceptado: 30 de Mayo de 2020

Disponible en línea: 01 de Agosto 2020

Double Blind Review System

Editor Científico

Ilan Avrichir

\section{Palabras-clave:}

Internacionalización

Teoría de Redes

Tecnología de la Información

Multinacionales de Mercados

Emergentes

\begin{abstract}
RESUMEN
Objetivo: Este estudio tiene como objetivo analizar los procesos de internacionalización de dos empresas brasileñas de TI desde la perspectiva de las redes de negocio, buscando entender las razones que llevaron a estas empresas a la internacionalización, los factores que influyen en el proceso y, sobre todo, la importancia de las redes de negocio.

Método: un enfoque cualitativo, basado en método de estudio de caso múltiple.

Principales resultados: Se encontró que, aunque las empresas se internacionalizaban por diferentes razones y de diferentes maneras, las proposiciones de la Teoría de la Red, en mayor o menor medida, eran lo suficientemente robustas como para explicar ambos procesos de internacionalización. Además, en el caso de que las redes de relaciones desempeñaran un papel más relevante, la velocidad de la internacionalización fuera mayor que en la otra.

Relevancia / Originalidad: Este estudio aborda dos brechasde iteración observadaspor Chetty y Stangl (2010): i) el estudio de las pequeñas y medianas empresas en relación con la internacionalización, la innovación y las redes; y (ii) la prueba cualitativa de las propuestas planteadas por los autores sobre estos temas.

Contribuciones: Ambas gerenciasestán haciendo hincapié en los directivos y empresarios la importancia de las redes de relaciones para la internacionalización de las empresas, utilizando casos reales y académicos, contribuyendo a la literatura sobre internacionalización de empresas y teoría de redes (NT).
\end{abstract}

\section{Cite it like this:}

Mello, R., Barreto, L., \& Kogut, C. (2020). Networks and Speed of Internationalization: A Multiple Case Study of Emerging Market IT Firms. Internext, 15(3), 01-16. doi:http://dx.doi.org/10.18568/internext.v15i3.585 